Soziologie - Sociology in the German-Speaking World 



\section{Soziologie - Sociology in the German-Speaking World}

Special Issue Soziologische Revue 2020

Edited by

Betina Hollstein, Rainer Greshoff, Uwe Schimank, and Anja Weiß 
ISBN 978-3-11-062333-8

e-ISBN (PDF) 978-3-11-062727-5

e-ISBN (EPUB) 978-3-11-062351-2

ISSN 0343-4109

DOI https://doi.org/10.1515/9783110627275

\section{(cc) BY-NC-ND}

This work is licensed under a Creative Commons Attribution-NonCommercial-NoDerivatives 4.0 International License. For details go to https://creativecommons.org/licenses/by-nc-nd/4.0/

\section{Library of Congress Control Number: 2020947720}

\section{Bibliographic information published by the Deutsche Nationalbibliothek} The Deutsche Nationalbibliothek lists this publication in the Deutsche Nationalbibliografie; detailed bibliographic data are available on the Internet at http://dnb.dnb.de.

(C) 2021 Betina Hollstein, Rainer Greshoff, Uwe Schimank, and Anja Weiß, published by Walter de Gruyter GmbH, Berlin/Boston

Printing and binding: $\mathrm{CPI}$ books $\mathrm{GmbH}$, Leck

www.degruyter.com 